\title{
Population Structure and Somatic Indexes of Hypostomus cf. ancistroides (Siluriformes, Loricariidae) Collected from the Bonito River, Ivaí River Basin, Turvo, Paraná
}

\author{
Douglas Viana ${ }^{1}$, Luciano Lazzarini Wollf ${ }^{1}$, Tânia Zaleski ${ }^{2}$, Silvia Romão ${ }^{2}$, Gustavo \\ Bertoldi $^{1}$ and Lucélia Donatti. ${ }^{1 *}$ \\ ${ }^{1}$ Universidade Federal do Paraná; Departamento de Biologia Celular; C.P 19031; 81531-970; Curitiba - PR - \\ Brazil. ${ }^{2}$ Universidade Federal do Paraná; Curitiba - PR - Brazil
}

\begin{abstract}
This study aimed to provide information about the population structure and somatic index of Hypostomus cf. ancistroides collected from the Bonito river, located in the Ivaí river basin. The length-weight relationship was isometric for both the sexes. The length structure analysis showed that the larger individuals (from $18.1 \mathrm{~cm}$ to $27.0 \mathrm{~cm}$ in length) predominated, and the lowest abundances occurred at the size extremes (9.1-12 cm and 27.1$30.0 \mathrm{~cm})$. The reproduction period occured between October and January for the females and between November and January for the males. The liver somatic index cannot be used as an indicator of the reproduction period in either of the sexes, due to no correlation between the liver somatic index and the gonad somatic index. The gonad weight exerted no influence on the monthly mean condition factor and the correlation between the condition factor and gonad somatic index was high. The condition factor could be an indicator of the reproduction period of this species.
\end{abstract}

Key words: Gonad somatic index, liver somatic index

\section{INTRODUCTION}

The Knowledge of the fish populations is of great importance, since the Brazilian rivers have been suffering increasing anthropogenic impacts and alterations. The population structure analysis helps interpreting many aspects of the life strategy of a given species, such as the energy to the growth, reproduction and maintenance. Some authors have studied the ichthyofauna diversity and ecology in the Brazilian rivers (Araújo, 1996; Castro, 1997; Vazzoler et al., 1997; Aranha et al., 1998; Aranha and Caramaschi, 1999; Uieda and Barreto, 1999;
Vieira, 2000; Lemes and Garutti, 2002; Pavanelli and Caramaschi, 2003; Duboc and Abilhoa, 2004; Abilhoa and Bastos, 2005; Haluch and Abilhoa, 2005; Tejerina-Garro et al., 2005). As many of these studies characterized the ichthyofauna of large hydrographic basins, the knowledge of population structures in small rivers, whose ecosystems displayed a high degree of endemismis has been unsatisfactory.

The population structure of many species of the Bonito river is still unknown. Changes along the river course resulting from the anthropic action have been detected in the last few years.

${ }^{*}$ Author for correspondence 
Riparian vegetation are being cleared and there are virtually no fringing forests in some stretches, because the river waters are used for the industrial purposes and the riverbanks for the agriculture.

The species under study belongs to the commonest genus (Hypostomus) in the family Loricariidae. It exclusively inhabits the South America, preferably the tropical regions of Brazil (Uieda, 1984; Power, 1984a). The ability of these hypostomins to survive in the diverse Neotropical river environments called the attention at Lowe McConnell (1963). She identified many species of Hypostomus as common species dwelling in small tributary environments, having sandy and/or rocky bottoms in the hydrographic basin of the Rupununi River, British Guyana.

Several hypostomins are known for a closer association with fast flowing environments where they display a bottom-dwelling behavior, feeding on the attached algae (Garavello and Garavello, 2004). The hypostomins are active mostly after the sunset; during the day they remain under rocks or submerged logs (Weber, 2003), but such a pattern is not a rule and it may vary according to the body size (Power, 1984b, Buck and Sazima, 1995). Power (1990) and Antoniassi et al. (1998) observed the environmental preferences of Hypostomus species for the clean and running waters of the large Brazilian rivers, and reported that this species not only withstaoo the barrage events but could also benefit by the luminous environments below the dam.

The present work aime at providing some information regarding the population structure and somatic index of Hypostomus cf. ancistroides collected at two sampling sites from the Bonito river - Turvo - Paraná state.

\section{METHODS}

\section{Study area}

The Bonito river, at about $798 \mathrm{~m}$ above sea level, is located in the Ivaí river basin in the state of Paraná and forms the border between the cities of Turvo and Boa Ventura de São Roque (25 $10^{\circ} \mathrm{S}$, $24^{\circ} 40^{\prime} \mathrm{S}$ and $51^{\circ} 40^{\prime} \mathrm{W}, 51^{\circ} 20^{\prime} \mathrm{W}$ ) (Fig. 1).

Figure 1 - Bonito river, located in the Ivaí river basin in the state of Paraná

From its headwaters, the Bonito river flows through the Serra Geral, Pirambóia, Botucatu and Rastro river formations, extending eastward from Turvo to its mouth, where it joins, from the south, the left bank of the Ivaí river. There are fast and slow flowing stretches. Mean depth does not exceed $1.5 \mathrm{~m}$ throughout most of the year, and deeper portions alternate. The substrate is rocky and there is little sediment deposition (found mainly along the margins). For the most part, the sediment is composed of branches, small trunks and particulate matter.

\section{Sampling and processing}

Throughout a year (March/2003 - February/2004), monthly samples were collected with a passive capture device: gill nets that were $20 \mathrm{~m}$ in length and $1.5 \mathrm{~m}$ in width, with different mesh sizes (1.5, $2.0,2.5$ and $3.0 \mathrm{~cm}$ bar measure). Two sampling sites were chosen in the middle river. They had a maximum depth of $1.5 \mathrm{~m}$ and a width ranging 


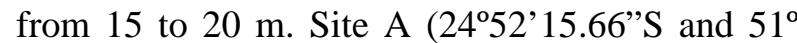
$\left.26^{\prime} 55.02^{\prime \prime} \mathrm{W}\right)$ was an area of still water; site B (24'51'54.18'S and 51'26'44.01'W) was an area of fast water. The samples were placed in the plastic bags for transport to the laboratory. The following information was gathered for each individual: total length (TL), standard length (SL), sex, total weight (TW), gonad weight (GW), and liver weight (LW). The temperature, $\mathrm{pH}$ and dissolved oxygen (Winkler methods) were measured.

\section{Data analysis}

The species constancy for $H$. cf. ancistroides was determined for the sampling sites A and B according to Dajoz (1973) and depending on the frequency of the occurrence in the samples, the species was classified as accidental (down to $25 \%$ ), accessory (from 25 to $50 \%$ ) or constant (above 50\%). The determination of the males, females and juveniles was carried throught the microscopical analysis (Vazzoler, 1996). The gonads were fixed in the formol $4 \%$, embedded in the Paraplast Plus ${ }^{\circledR}$ and stained with haematoxylin and eosin (H.E.; Bücherl, 1962). The lengthweight relationships were calculated for the whole sample and separately for the males and females, so that it could be observed whether the figures for the males and females would fall within the confidence interval for the whole sample. If they did, the lines for the males and females would be considered the same. To analyze the size composition, specimens were assigned to the size groups as defined by Sturges (Silva and Souza, 1987). To determine whether these results were statistically valid, the chi-square test $\left(\chi^{2}\right)$ was used whenever possible, assuming $\alpha=0.05$.

The gonad somatic index (GSI) was the ratio of the gonad weight (GW) versus total body weight (TW), expressed as a percentage of the total body weight. The liver somatic index (LSI) was calculated by dividing the total weight of the liver (LW) by the total body weight (TW) and multiplying the result by 100 . The condition factor (K) was computed by the equation $\mathrm{K}=\mathrm{TW} / \mathrm{TL}^{b}$ where $b$ was the coefficient of allometry determined from the length-weight relationship (Querol et al., 2002). The influence gonad weight exerted on the mean condition factor was assessed by the formula $\mathrm{K}_{\mathrm{g}}=(\mathrm{TW}-\mathrm{GW}) / \mathrm{TL}^{b}$ where $\mathrm{K}_{\mathrm{g}}$ was the gonad condition factor $\left(\mathrm{K}^{`}\right)$. Pearson's correlation was performed to determine whether there were associations between gonad somatic index and condition factor and between the gonad somatic index and liver somatic index.

\section{RESULTS}

From March/2003 to February/2004, 327 specimens (males $=127$ and females $=107$ ) of $H$. cf. ancistroides were collected from the Bonito river. The annual mean temperature at site $\mathrm{A}$ was $18.0 \pm 2.0^{\circ} \mathrm{C}$, the $\mathrm{pH}$ was $6.5 \pm 1.0$ and dissolved oxygen was $8.0 \pm 4.0 \mathrm{mg} / \mathrm{L}^{-1}$. At site $\mathrm{B}$ the temperature was $18.0 \pm 1.0^{\circ} \mathrm{C}$, the $\mathrm{pH}$ was $6.5 \pm$ 1.0 and dissolved oxygen was $8.0 \pm 4.0$.

Hypostomus cf. ancistroides was a constant species in the Bonito river. Its frequency of occurrence was above $50 \%$ in the two studied biotopes.

The length-weight relationship at sampling sites A and $\mathrm{B}$ was isometric for both the sexes. For the females, the equation $\mathrm{TW}=2.44 \times \mathrm{TL}-2.99$ showed $90.2 \%$ (Fig. 2A) of the variance obtained; for the males, the equation $\mathrm{TW}=2.66 \times \mathrm{TL}-3.74$ showed $82.3 \%$ (Fig. 2B) of the variance obtained. The lines obtained for the each sex in the lengthweight relationship did not fit entirely within the confidence limits for the whole sample. Based on total length, seven size classes were defined with 3 $\mathrm{cm}$ amplitude. The total length of Hypostomus cf. ancistroides ranged from $9.0-12.0 \mathrm{~cm}$ to $27.1-30.0$ cm classes (Table 1).

All the size classes showed a higher capture rate at sampling site A, except for the class 1 . The males were predominant in all the size classes, except for class 6 , in which the females were significantly more frequent $\left(\chi^{2}=12.4 ; \mathrm{P}=0.0004 ;\right.$ d.f. $\left.=1\right)$. At though the males were predominant in the other size classes, it was only in class $2\left(\chi^{2}=4.19 ; \mathrm{P}=\right.$ 0.04 ; d.f. $=1$ ) that this predominance was significant. There was no significant difference in the sex proportion, neither in the whole sample nor in each of the sampling sites. The monthly sex proportion showed that the males were significantly dominant only in February $\left(\chi^{2}=5.60\right.$; $\mathrm{P}=0.02$; d.f. = 1; Fig. 3). 

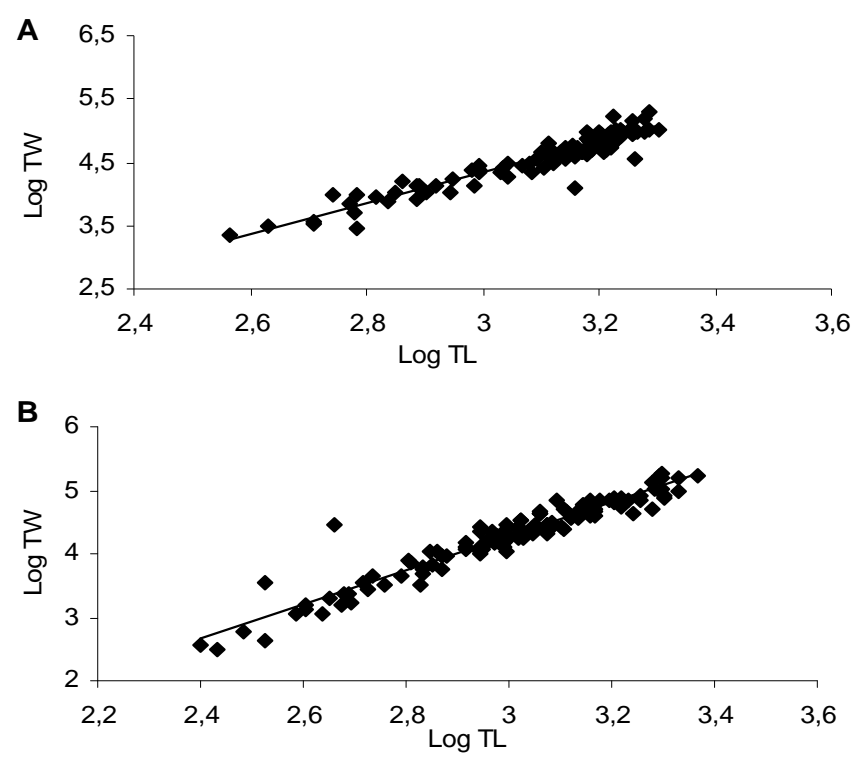

Figure 2 - Lenght-weight relationship of $H$. cf. ancistroides for females (A) and males (B).

Table 1 - Amplitude of size classes of $H$. cf ancistroides for females (F), males (M) and juveniles (J) and for sites A e B.

\begin{tabular}{cccccccc}
\hline \multirow{2}{*}{ Classe } & \multirow{2}{*}{ Length $(\mathbf{c m})$} & \multicolumn{3}{c}{$\mathbf{n}(\mathbf{A})$} & & \multicolumn{2}{c}{$\mathbf{n}(\mathbf{B})$} \\
\cline { 3 - 7 } & & $\mathbf{F}$ & $\mathbf{M}$ & $\mathbf{J}$ & $\mathbf{F}$ & $\mathbf{M}$ & $\mathbf{J}$ \\
\hline 1 & $9.0-12.0$ & 0 & 1 & 7 & 0 & 2 & 8 \\
2 & $12.1-15.0$ & 0 & 9 & 11 & 4 & 3 & 6 \\
3 & $15.1-18.0$ & 8 & 12 & 12 & 4 & 5 & 4 \\
4 & $18.1-21.0$ & 12 & 39 & 21 & 3 & 2 & 9 \\
5 & $21.1-24.0$ & 21 & 25 & 12 & 9 & 7 & 3 \\
6 & $24.1-27.0$ & 37 & 11 & 0 & 7 & 0 & 0 \\
7 & $27.1-30.0$ & 1 & 4 & 0 & 0 & 1 & 0 \\
\hline
\end{tabular}

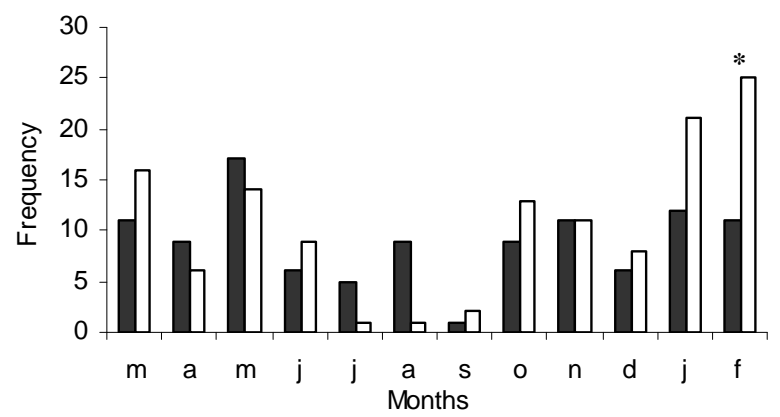

Figure 3 - Monthly sex proportion of $H$. cf. ancistroides (March/2003 to February/2004). * = significant difference; white bar = males; black bar = females 
The highest liver somatic indices were observed in October and November for the females (Fig. 4A) and in March, October and

November for the males (Fig. 4B). The mean liver somatic index was 0.44 (SE: \pm 0.05 ) in the males and 0.42 (SE: \pm 0.02 ) in the females. There was no correlation between the gonad somatic index and liver somatic index (females: $r=0.07$; males: $r=$ 0.12). As to the gonad somatic index, the highest indices for the females were observed from October to December while the lowest ones were observed in February and June (Fig. 4C). The males presented their highest indices in June and November and the lowest ones in April and May (Fig. 4D). The mean gonad somatic index was 3.30 (SE: \pm 0.42) in the females and 0.23 (SE: \pm $0.03)$ in the males. The correlation between the gonad somatic index and the condition factor was low (females: $r=0.45$; males: $r=0.14$ ).

The females presented high condition factor in October (5.88 \pm 0.19 , mean \pm SD) and November (5.51 \pm 0.16 , mean \pm SD) and low condition factor in April (4.67 \pm 0.31 , mean \pm SD) and March (4.68 \pm 0.12 , mean $\pm \mathrm{SD})$. The males presented their highest in December $(2.98 \pm 0.61$, mean \pm SD) and May (2.69 \pm 0.07 , mean \pm SD) and the lowest ones in March $(2.22 \pm 0.05$, mean \pm SD) and January (2.28 \pm 0.11 , mean \pm SD; Table 2).

The gonad weight exerted no influence on the monthly mean condition factor of Hypostomus sp. The correlation between condition factor and gonad somatic index was high (males: $\mathrm{r}=0.97$; females: $r=0.99$; Figs. 5A, B).
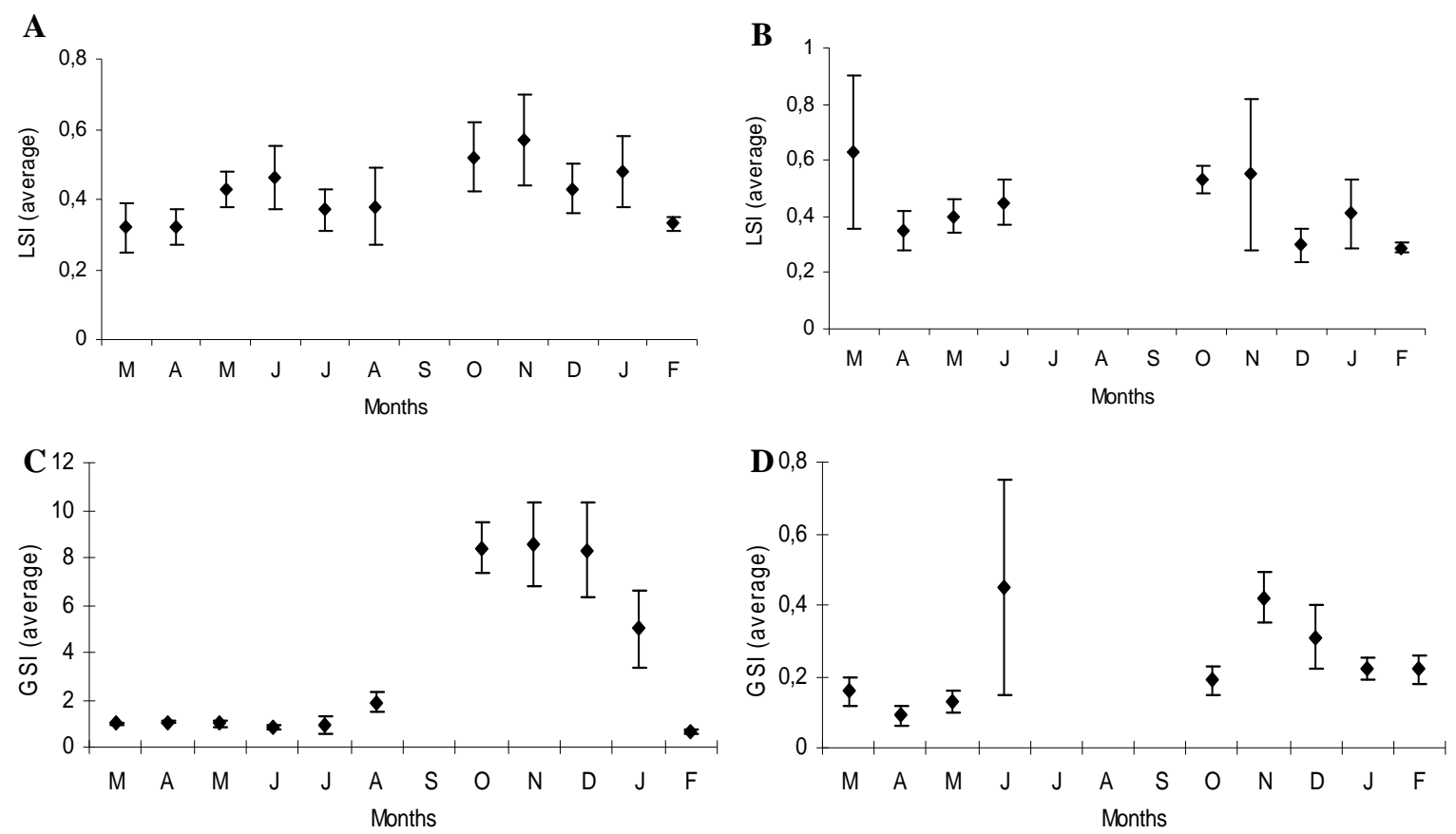

Figure 4 - A: Monthly mean \pm SD liver somatic index (LSI) for females $(n=105)$ in the Bonito river. B: Monthly mean \pm SD liver somatic index $(\mathrm{LSI})$ for males $(\mathrm{n}=125)$ in the Bonito river. C: Monthly mean \pm SD gonad somatic index $(\mathrm{GSI})$ for females $(\mathrm{n}=104)$ in the Bonito river. D: Monthly mean \pm SD gonad somatic index $(\mathrm{GSI})$ for males $(\mathrm{n}=105)$ in the Bonito river 


\section{DISCUSSION}

In this study, the abundance and constancy for $H$. cf. ancistroides seemed to be associated with the physiographical features of the Bonito river. The fast and slow flowing stretches, the rocky substrate with little sediment deposition, and the depths not exceeding $1.5 \mathrm{~m}$ throughout most of the year constituted a favorable environment for the macro algae to settle and develop. According to Power (1990), most of the species that belong to the genus Hypostomus are limited to the bottom and forage on algae.

$H$. cf. ancistroides proved to be a constant species in the Bonito river. Abundance was higher at sampling site A (still water stretch). Lemes and Garutti (2002) analyzed the species constancy in subsequent biotopes in a faster and in a slower area; they reported that the frequency of occurrence seemed to be influenced by the preference for the biotopes, by the ontogenetic stages of the species and by the seasonal plasticity of the biotopes. The higher abundance of $H$. cf ancistroides at sampling site A seemed to be associated with the presence of a tributary brook to the Bonito river. Duarte and Araújo (2001), studying the abundance and distribution of the catfish Loricariicchthys spixii in the Lajes reservoir, Rio de Janeiro, associated the higher abundance in the upper zone of the reservoir with the presence of tributary brooks.

The weight, in the fish, may be influenced by the intrinsic (physiological) and extrinsic (environmental). Data on the weight and length may indicate the well-being or health of a species (Rossi-Wongtschowski, 1977; Tavares-Dias et al., 2000). It was observed in this study that the length-weight relationship was isometric for both the males and females. The same relationship was found in some sea fish by Braga (1986), in Hypostomus aff. Plecostomus by Barbieri and Verani (1987) and in Rhinelepis aspera by Agostinho et al., (1990).

Table 2 - Monthly mean \pm SD condition factor $(\mathrm{K})$ and gonad condition factor $\left(\mathrm{K}^{\prime}\right)$ of $H$. cf. ancistroides for females (F) and males (M).

\begin{tabular}{lcccc}
\hline & \multicolumn{2}{c}{ K } & \multicolumn{2}{c}{$\mathbf{K}^{\prime}$} \\
\hline Months & $\mathbf{F}$ & $\mathbf{M}$ & $\mathbf{F}$ & $\mathbf{M}$ \\
\hline March & $4.68 \pm 0.12$ & $2.22 \pm 0.05$ & $4.64 \pm 0.12$ & $2.24 \pm 0.05$ \\
Abril & $4.67 \pm 0.31$ & $2.48 \pm 0.08$ & $4.62 \pm 0.31$ & $2.48 \pm 0.08$ \\
May & $4.75 \pm 0.09$ & $2.69 \pm 0.07$ & $4.70 \pm 0.09$ & $2.27 \pm 0.07$ \\
June & $4.94 \pm 0.07$ & $2.34 \pm 0.07$ & $4.9 \pm 0.07$ & $2,33 \pm 0.07$ \\
July & $4.95 \pm 0.22$ & & $4.90 \pm 0.22$ & \\
August & $5.22 \pm 0.15$ & & $5,12 \pm 0.14$ & $2.75 \pm 0.07$ \\
October & $5.88 \pm 0.19$ & $2.75 \pm 0.07$ & $5.38 \pm 0.15$ & $2.43 \pm 0.23$ \\
November & $5.51 \pm 0.16$ & $2.44 \pm 0.23$ & $5.04 \pm 0.18$ & $2.97 \pm 0.61$ \\
December & $5.24 \pm 0.01$ & $2.98 \pm 0.61$ & $4.80+0.14$ & $2.28 \pm 0.11$ \\
January & $5,18 \pm 0.14$ & $2.28 \pm 0.11$ & $4.94 \pm 0.15$ & $2.42 \pm 0.06$ \\
February & $4.73 \pm 0.23$ & $2.42 \pm 0.06$ & $4.70 \pm 0.23$ & \\
\hline
\end{tabular}

The lines obtained for each sex in the lengthweight relationship did not fit entirely within the confidence limits for the whole sample, hence it could be inferred that the males and females had different individual growth patterns. This could be ascribed to the variation in the gonad and stomach weights (Basile-Martins et al., 1978; Papageorgiou, 1979; Narahana, 1983). The gonads may represent up to $15 \%$ of total weight and the stomach up to $30 \%$ (Nikolski, 1963).

The length structure analysis of $H$. cf. ancistroides showed that the larger individuals predominated. Agostinho et al. (1990), studying Rhinelepsis aspera in the Paranapanema river, observed a higher abundance of individuals from 25 to $45 \mathrm{~cm}$ in length, whereas the lowest abundances occurred 
at the size extremes $(5-10 \mathrm{~cm}$ and $50-55 \mathrm{~cm})$. The same thing was observed for $H$. $\mathrm{cf}$.ancistroides in the Bonito river.

As to sex proportion, the males were predominant in all the size classes, except for the class six. Selective predation may alter the sex proportion by diminishing the percentage of the males (Krumholtz, 1948) or of the females (Britton and Moser, 1982). Boely apud Narahara et al. (1985) that the sex proportion could be related to the length of individuals. In the Bonito river, the differences in the growth and mortality rates were probably affecting the sex proportion that was found.

The gonad somatic index analysis for the females of $H$. cf. ancistroides showed that the reproduction period occured between October and January. The gonad development began in August and had its peak in October. According to Barbieri and Verani (1987), this was the same reproduction period for the catfish Hypostomus aff. Plecostomus in Monjolinho dam in the city of São Carlos (SP). The increment in the gonad somatic index was also observed by Querol et al. (2002) for the catfish Loricariichthys platymetopon from the Uruguai Bay. Querol et al. (2002) found that an increase in temperature could influence an increase in the gonad somatic index. This confirmed the results for $H$. cf. ancistroides in the Bonito river. Through the spring until the summer, the highest temperatures and the highest gonad somatic indices were registered. The mean gonad somatic indices indicated the same reproduction period (between November and January) for the males and females.

The liver somatic index could be related to the stored energy mobilization for the vitellogenesis, reproduction and preparation for the winter (Querol et al., 2002). This index cannot be used as an indicator of the reproduction period in either of the sexes, due to the low correlation between the liver somatic index and the gonad somatic index. The highest indices for the females occurred in October and November to decrease progressively throughout the following months. For the males, instead, no temporal pattern was observed. Barbieri et al. (1996) observed that the mean liver somatic indices increased when the gonad maturation began and decreased until the final maturation and spawning. Agostinho (1985) reported a progressive reduction in the mean condition factor and liver somatic index of Rhinelepis aspera during the gonad maturation period.

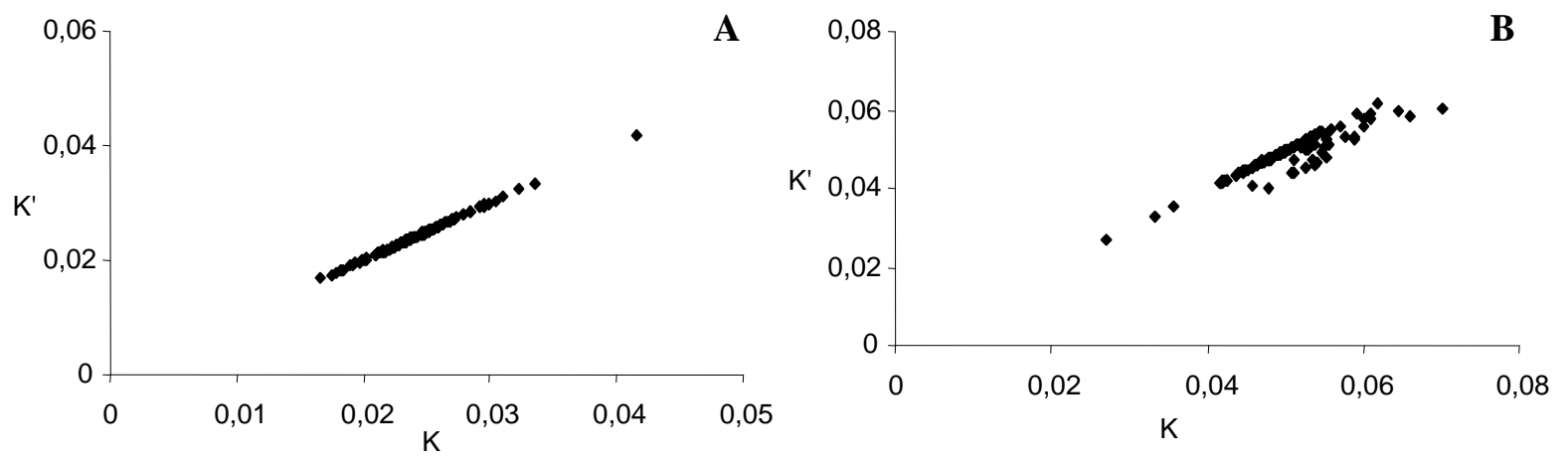

Figure 5 - Correlation between condition factor $(\mathrm{K})$ and gonad condition factor $\left(\mathrm{K}^{`}\right)$ for females $(\mathrm{n}=$ 106) (A) and males $(\mathrm{n}=127)(\mathbf{B})$ in the Bonito river

Le Cren (1951) reported the variations in the condition factor that those could be during the reproduction cycle. MacGregor (1959) found that the nutritional states played a preponderant role in these variations. When the exponent in the formula was 3 , the condition factor could increase or decrease as the size of the fish increased (Braga, 1986). The variations in the condition factor were associated with both the reproduction cycle and nutritional states (Barbieri and Afonso-Marins, 1995). Barbieri and Verani (1987) observed that the condition factor and the relative liver weight were reduced by the cyclic gonad maturation and the reproduction cycle. It could be inferred that the correlation between the gonad condition factor and gonad somatic index was high, since the 
correlation coefficients for the males and females were 0.97 and 0.99 , respectively. The results for $H$. cf. ancistroides in the Bonito river were similar to those obtained by Isaac-Nahum and Vazzoler (1983) for Micropogonias furnieri (Desmarest, 1823), by Barbieri and Verani (1987) for $H$. aff. Plecostomus (Linnaeus, 1758), by Barbieri et al. (1996) for Astyanax fasciatus (Cuvier, 1819) and by Querol et al. (2002) for Loricariichthys platymetopon.

\section{RESUMO}

Este estudo teve o objetivo de fornecer informações sobre a estrutura populacional e os índices somáticos de Hipostomus cf. ancistroides coletados no rio Bonito localizado na bacia do rio Ivaí. A relação comprimento-peso, para machos e para fêmeas, foi isométrica. A análise da estrutura em comprimento mostrou que há um predomínio de indivíduos maiores (entre 18.1 a $27.0 \mathrm{~cm}$ ) sendo que as menores abundâncias ocorreram nas classes de comprimentos extremas $(9.1 \mathrm{a} 12.0 \mathrm{~cm}$ e 27.1 a $30.0 \mathrm{~cm}$ ). O período reprodutivo em fêmeas ocorreu entre os meses de outubro a janeiro. Os machos possuem um período reprodutivo entre novembro e janeiro. $\mathrm{O}$ índice hepatossomático, para ambos os sexos, não pode ser utilizado como indicador do período reprodutivo, devido à não correlação entre o índice hepatossomático e o índice gonadossomático. $\mathrm{O}$ peso das gônadas não influenciou o valor médio do fator de condição e foi observada uma alta correlação entre o fator de condição e o índice gonadossomático. O fator de condição pode ser um indicador do período de reprodução desta espécie.

\section{REFERENCES}

Abilhoa, V. and Bastos, P. (2005), Composição e estrutura da ictiofauna da Estação Ecológica do Caiua, área de influência da UHE de Rosana (Rio Paranapanema) sudeste do Brasil. Arquivos de Ciências Veterinárias e Zoologia da Unipar, 8: (1), 33-39.

Agostinho, A. A. (1985), Estrutura da População, Idade e Crescimento de Rhinelepis áspera (Osteichthyes, Loricariidae) do Rio Paranapanema $P R$. PhD Thesis, Universidade Federal de São Carlos, São Carlos, Brasil.
Agostinho, A. A.; Barbieri, G.; Verani, J.R. and Hahn, N.S. (1990), Variação do fator de condição e do índice hepatossomático e suas relações com o ciclo reprodutivo em Rhinelepis aspera (Agassis, 1829) (Osteichthyes, Loricariidae) no rio Paranapanema, Porecatu, PR. Ciência e Cultura, 24: (9), 711-714.

Antoniassi, L. E.; Agostinho, A. A.; Gomes, I. C. and Hahn, N. S. (1998), Ecologia trófica de peixes em dois riachos da bacia do Rio Paraná. Rev. Bras. Biol., 58: (2), 273- 285.

Aranha, J. M. R. and Caramaschi, E. P. (1999), Estrutura populacional, aspectos da reprodução e alimentação dos Cyprinodontiformes (Osteichthyes) de um riacho do sudeste do Brasil. Revta Bras. Zool., 16: (1), 637-651.

Aranha, J. M. R; Takeuti, D. F. and Yoshimura, T. M. (1998), Habitat use and food partioning of the fishes in a coastal stream of Atlantic Forest, Brazil. Rev. Biol. Trop., 46: (4), 951-959.

Araújo, G. F. (1996), Composição e estrutura da comunidade de peixes do médio e baixo Rio Paraíba do Sul, RJ. Rev. Bras. Biol., 56: (1), 11-126.

Barbieri, G. and Afonso-Marins, M. (1995), Estudo da dinâmica da reprodução de fêmeas de Astyanax bimaculatus (Linnaus, 1758) da represa do Lobo, Estado de São Paulo (Osteichthyes, Characidae). Arq. Biol. Tecnol,. 38: (54), 1191-1197.

Barbieri, G. and Verani, R. J. (1987), O fator de condição como indicador do período de desova em Hypostomus aff. Plecostomus (Linnaeus, 1758) (Osteichthyes, Loricariidae), na Represa Monjolinho (São Carlos, SP). Ciência e Cultura, 39: (7), 655658.

Barbieri, G.; Hartz, S.M. and Silveira, C.M. (1996), O fator de condição e índice hepatossomático como indicadores do período de desova de Astyanax fasciatus da Represa do Lobo, São Paulo (Osteichthyes, Characidae). Ilheringia. Ser. Zool., 81, 101-104.

Basile-Martins, M.A.; Cipóli, M.N. and Godinho, H.M. (1978), Comportamento e alimentação do mandi Pimelodus maculatus Lacépède, 1803 (Osteichthyes, Pimelodidae) de trechos dos rios Jaguari e Piracicaba, São Paulo - Brasil. Boletim do Instituto de Pesca, 13: (1), 17-29.

Braga, F.M.S. (1986), Estudo entre fator de condição e relação peso/comprimento para alguns peixes marinhos. Rev. Bras. Biol., 46: (2), 339-346.

Britton, R.H. and Moser, M.E. (1982), Size specific predation by herons and its effect on the sex-radio of natural populations of the mosquito fish Gamburia affinis baird and girard. Oecologia, 53: (2), 146-151.

Bücherl, W. (1962), Técnica microscópica. São Paulo: Ed. Polígono. 164p.

Buck, S. and Sazima, I. (1995), An assemblage of mailed catfishes (Loricariidae) in southeastern Brazil: distribution, activity, and feeding. Ichthyol. Explor. Freshwaters, 6, 325-332. 
Castro, A. C. L de. (1997), Aspectos ecológicos da comunidade ictiofaunística do resevatório de Barra Bonita, São Paulo. Rev. Bras. Biol., 57: (4), 665-676.

Dajoz, R. (1973), Ecologia Geral. São Paulo : Editora Vozes Ltda. $2^{\circ}$ ed.

Duarte, S. and Araújo, G. S. (2001), Abundância relativa de Loricariichthys spixii (Steindachner) (Siluriformes, Loricariidae) no reservatório de Lajes, Rio de Janeiro ,Brasil. Rev. Bras. Zool. 18: (2), 465477.

Duboc, L..F. and Abilhoa, V. (2004), Rachoviscus crassiceps Myers, 1926 (Characiformes : Characidae: Incertae sedis), um caracídeo ainda pouco conhecido em seu ambiente natural. Boletim da Sociedade Brasileira de Ictiologia, 74, 6-8.

Garavello, J.C. and Garavello, J.P. (2004), Spatial distribution and interaction of four species of the catfish genus Hypostomus Lacépède with bottom of Rio São Francisco, Canindé do São Francisco, Sergipe, Brazil (Pisces, Loricariidae, Hypostominae). Braz. J. Biol., 64B, 591-598.

Haluch, C. F. and Abilhoa, V. (2005), Astyanax totae, a new characid species (Teleostei, Characidae) from the upper river Iguaçu basin, southeastern Brasil. Neotropical Ichthyology, 3: (3), 383-388.

Isaac-Nahum, V.J. and Vazzoler, A.E.A.M. (1983), Biologia reprodutiva de Micropogonias furnieri (Desmarest, 1923) (Teleostei, Scienidae). 1. Fator de condição como indicador do período de desova. Bolm. Inst. Oceanogr., 32: (1), 63-69.

Krumholz, L. A. (1948), Reproduction in the western mosquito-fish Gambusia affinis (Baird and Giard), and its use in mosquito control. Ecol. Monog., 18, 143.

Le Cren, E.D. (1951), The length-weight relationship and seasonal cycle in gonadal weight and condiction in the perch, Perca flaviatilis. J. Animal. Ecol., 20: (2), 210-219.

Lemes, M. E. and Garutti, V. (2002), Ecologia de um córrego de cabeceira da Bacia do Alto Rio Paraná, Brasil. Iheringia. Ser. Zool., 92: (3), 69-78.

Lowe Mcconnell, R. H. (1963), The fishes of the Rupununi savanna district of British Guiana, South America. Part 1. Ecological groupings of fish species and effects of the seasonal cycle of the fish. J. Linn. Soc. Ser. Zool., 45: (304), 103-144.

MacGregor, J. S. (1959), Relation between fish condiction population size in the sardine (Sardinops caerulea). Fish. Bull., 60: (166), 215-230.
Narahara, M. Y. (1983), Estrutura da população de Rhamdia hilarii (Valenciennnes, 1840) (Osteichthyes, Siluriformes, Pimelodidae). PhD Thesis, Instituto de Biociências, Universidade de São Paulo, São Paulo, Brasil.

Narahara, M. Y.; Godinho, H.M.; Fenerich-Verani, N. and Romagosa, E. (1985), Relação peso-comprimento e fator de condição de Rhamdia hilarii (Valenciennes, 1840) (Osteichthyes, Siluriformes, Pimelodidae). Boletim do Instituto de Pesca, 4: (12), 13-22.

Nikolski, G. V. (1963), The ecology of fishes. London, Academic press, 352p.

Pavanelli, C.S. and Caramaschi, E.P. (2003), Temporal and spatial distribution of the ichthyofauna in two streams of the upper Rio Paraná basin. Braz. Arch. Biol. Technol., 46: (2), 271-280.

Papageorgiou, N. K. (1979), The length weight relationship, age, growth and reproduction of the roach Rutilus rutilus (L.) in the lake Volvi. Journal Fish Biology, 14: (16), p. 529-538.

Power, M. E. (1984a), Grazing responses to tropical freshwater fishes to differente scales of variation in their food. In - Evolutionary ecology of Neotropical Freswater Fishes (T. M. Zaret, ed.). Dr. W. Junk Publishers, The Hague, Netherlands. 25-37.

Power, M. (1984b), Depth distributions of armored catfish: predator-induced resource avoidance. Ecology, 65, 523-528.

Power, M. E. (1990), Resource enhacement by indirect effects of grazers: Armored Catfish, Algae, and Sediment. Ecology, 71, 897-904.

Querol, M.V.M.; Querol, E. and Gomes, N.N.A. (2002), Fator de condição gonadal, índice hepatossomático e recrutamento como indicadores do período de reprodução de Loricariichthys platymetopon (Osteichhyes, Loricariidae), Bacia do Rio Uruguai Médio, Sul do Brasil. Iheringia. Ser. Zool., 92: (3), 79-84.

Rossi-Wongtschowski, C.L.B. (1977), Estudo das variações da relação peso total/comprimento total em função do ciclo reprodutivo e comportamento de Sardinella brasiliensis (Steindachner, 1879) da Costa do Brasil entre $23^{\circ} \mathrm{S}$ e $28^{\circ} \mathrm{S}$. Bolm. Inst. Oceanogr., 26, 131-180.

Tejerina-Garro, F.L.; Maldonado, M.; Ibanez, C.; Pont, D.; Roset, N. and Oberdorff, T. (2005), Effects of natural and anthropogenic environmental changes on riverine fish assemblages: a framework for ecological assessment of rivers. Braz. Arch. Biol. Technol., 46:(2), 271-280.

Vazzoler, A.E.A. (1996), Biologia da reprodução de peixes teleósteos: teoria e prática.Maringá: EDUM. $169 \mathrm{p}$. 
Uieda, S. V. and Barreto, G. M. (1999), Composição de quatro trechos de diferentes ordens do Rio Capivara, Bacia do Rio Tietê, Botucatu, São Paulo. Rev. Bras. de Zoociências, 1: (1), 55-67.

Uieda, V. S. (1984), Ocorrência e Distribuição dos Peixes em um Riacho de Água doce. Rev. Bras. Biol. 44, 203-213.

Vazzoler, E. A. M de.; Agostinho, A. A. and Hahn, S. N. (1997), A planície de inundação do alto Rio Paraná. Maringá : Eduem - Nupélia.
Vieira, I. (2000), Freqüência, constância, riqueza e similaridade da ictiofauna da bacia do Rio Curua Una, Amazônia, Brasil. Rev. Bras. de Zoociências., 2: (2), 51-76.

Weber, C. (2003), Subfamily Hypostominae. In - Check list of the freshwater fishes of South and Central America (R.E. Reis; S.O. Kullander and C.J. Ferraris Jr., orgs.). Editora da Pontifícia Universidade Católica do Rio Grande do Sul, Porto Alegre, pp 351372. 